\title{
Penerapan Model Pembelajaran Kooperatif Tipe Co-op Co-op untuk Meningkatkan Hasil Belajar Matematika dan Motivasi Belajar
}

\author{
Ketut Sandiasa*
}

SMP Negeri 2 Abang Karangasem

A R T I C L E I N F O

Article history:

Received 10 May 2019

Received in revised form 15 June 2019

Accepted 29 July 2019

Available online

28 August 2019

\section{Kata kunci:}

Kooperatif tipe co-op co-op,

Hasil belajar matematika,

Motivasi belajar

Keywords:

Cooperative co-op co-op type,

Mathematics learning

outcomes,

Learning motivation

\section{A B S T RAK}

Penelitian ini merupakan penelitian tindakan kelas (PTK) yang bertujuan untuk memperbaiki proses pembelajaran yang berlangsung sehingga terjadi peningkatan hasil belajar dan motivasi belajar siswa. Objek penelitian ini adalah hasil belajar matematika dan motivasi belajar matematika siswa kelas IX A SMP Negeri 2 Abang tahun pelajaran 2018/2019. Subjek penelitian ini 30 orang siswa sebagai sumber data. Data hasil belajar dikumpulkan dengan metode tes dengan perangkat tes 15 butir. Data tentang motivasi belajar matematika dikumpulkan dengan metode kuesioner yang terdiri dari 10 butir. Data hasil penelitian dianalisis dengan teknik analisis deskriptif kuantitatif dengan kriteria keberhasilan tindakan rata-rata hasil belajar matematika minimal $76,00 \%$ dan ketuntasan belajar minimal 85,00\%. Berdasarkan hasil analisis data dapat disimpulkan bahwa: (1) penerapan model pembelajaran kooperatif tipe Co-op Co-op dapat meningkatkan hasil belajar matematika. Pada observasi awal rata-rata hasil belajar matematika siswa 69,20 dengan ketuntasan belajar 50\% meningkat pada siklus I menjadi 75,80 dengan ketuntasan belajar 66,70\%. Pada sikklus II meningkat menjadi 87,10 dengan ketuntasan belajar 93,30\%. (2) Penerapan model pembelajaran kooperatif tipe Coop Co-op dapat meningkatkan motivasi belajar matematika. Untuk variabel motivasi belajar pada siklus I memiliki rata-rata sebesar 75,10 dengan kategori sedang, dan pada siklus II dengan rata-rata 87,10 dengan ketegori tinggi. Berdasarkan hasil analisis tampak bahwa terjadi peningkatan motivasi belajar siswa sebesar 16,00\% dari kualifikasi sedang menjadi kualifikasi tinggi.

\section{A B S T R A C T}

This research is classroom action research (PTK) which aims to improve the learning process that takes place so that there is an increase in learning outcomes and student learning motivation. The object of this study is the learning outcomes of mathematics and motivation to learn mathematics students of class IX A Abang 2 Public Middle School 2018/2019 academic year. The subjects of this study were 30 students as data sources. Learning outcomes data were collected by the test method with a 15 items test device. Data on motivation to learn mathematics was collected by a questionnaire method consisting of 10 items. The results of the research data were analyzed by quantitative descriptive analysis techniques with the success criteria for action at least $76.00 \%$ of mathematics learning outcomes and learning completeness of at least $85.00 \%$. Based on the results of data analysis it can be concluded that: (1) the application of the cooperative learning model Co-op Co-op type can improve mathematics learning outcomes. In the initial observation the average mathematics learning outcomes of students 69.20 with learning completeness $50 \%$ increased in the first cycle to 75.80 with learning completeness $66.70 \%$. In cycle II it increased to 87.10 with $93.30 \%$ learning completeness. (2) The application of cooperative learning model Co-op Co-op type can increase motivation to learn mathematics. The learning motivation variable in the first cycle has an average of 75.10 in the moderate category, and in the second cycle with an average of 87.10 with a high category. Based on the results of the analysis it appears that there was an increase in student learning motivation by $16.00 \%$ from the qualifications being high qualifications. 


\section{Pendahuluan}

Pembelajaran hanya mengajarkan materi sesuai dengan urutan buku paket atau urutan buku lks saja, sehingga masih banyak guru beranggapan bahwa tuntas mengajar berarti sebatas puas mengajarkan materi atau aborsi pendidikan (Lasmawan, 2011). Strategi belajar mengajar semestinya tidak hanya terbatas pada hasil saja, melainkan proses pembelajaran juga termasuk didalamnya. Bahkan seringkali terjadi, dalam pembelajaran konsep matematika hanya menekankan pada hasil itu saja, aturan cukup dihafal, tidak perlu tahu pendekatan (Approachs) apa yang mestinya digunakan dan bagaimana pengetahuan awal siswa(Prior knowledge).

Akibat dari masalah tadi banyak siswa yang tidak termotivasi belajar matematika, yang mengakibatkan rendahnya kemampuan siswa dalam pemahaman konsep, manipulasi matematika dan penerapan matematika pada kehidupan sehari-hari. Hal ini juga terjadi pada hasil belajar matematika di SMP Negeri 2 Abang yang belum juga mengalami peningkatan hasil belajar. Hal ini terlihat berdasarkan data rata-rata nilai ulangan harian kelas IX A SMP Negeri 2 Abang tahun pelajaran 2018/2019 yang hanya baru mencapai 69,2 dengan ketuntasan klasikal 50\% artinya baru 15 orang siswa dari 30 siswa yang memperoleh nilai di atas 76. Berdasarkan data tersebut, maka hasil belajar matematika pada SMP Negeri 2 Abang masih perlu ditingkatkan karena rata-rata nilai berada di bawah KKM.

Menurut Puger (2004) untuk meningkatkan hasil belajar siswa diperlukan model pembelajaran yang dapat mengembangkan pemahaman konsep, penalaran dan motivasi dalam kegiatan belajar siswa. Salah satu faktor penentu keberhasilan belajar matematika bagi siswa SMP Negeri 2 Abang khusunya pada kompetensi memahami sifat-sifat BRL (bangun ruang sisi lengkung) adalah model pembelajaran yang dapat menumbuhkan pemahaman, penalaran, dan memotivasi kegiatan belajar siswa yaitu dengan menggunakan model pembelajaran kooperatif (cooperative learning) tipe Co-op Co-op. Dengan menggunakan model pembelajaran kooperatif tipe Co-op Co-op, maka pengungkapan konsep-konsep dalam suatu matematika dapat diwujudkan melalui cara-cara yang rasional, komunikatif, edukatif, dan menyenangkan (Quantum learning). Pembelajaran kooperatif tipe Co-op Co-op merupakan suatu model pengajaran dimana siswa belajar dalam kelompok-kelompok kecil yang memiliki tingkat kemampuan berbeda dalam menyelesaikan tugas kelompok. Setiap anggota saling bekerja sama dan membantu untuk memahami suatu bahan pembelajaran. Belajar belum selesai jika salah satu teman dalam kelompok belum menguasai bahan pembelajaran (Depdiknas, 2004).

Salah satu aspek lain, yang berpengaruh terhadap hasil belajar siswa menurut Marhaeni adalah motivasi belajar. Motivasi bersifat hasil belajar (learned), yaitu perubahan yang terjadi pada afeksi bawaan yang diakibatkan oleh adanya stimulus atau situasi afektif dari luar. Lebih lanjut Gardner (dalam Marhaeni, 2005) menekankan bahwa berdasarkan hasil-hasil penelitian yang dilakukan ditemukan bahwa variabel-variabel keberhasilan belajar bahasa asing sangat tergantung pada variabel motivasi. Motivasi merupakan perilaku ke arah suatu tujuan, dengan demikian motivasi merupakan pendorong seseorang untuk lebih giat berusaha untuk mencapai hasil terbaiknya. Satu dari sekian cara untuk mempelajari motivasi adalah dengan mempertimbangkan faktor-faktor nonfisiologis yang mempengaruhi perilaku. Henry Murray, sebagaimana dikutip oleh Marhaeni (2005) mengidentifikasi beberapa motif manusia. Salah satu di antaranya adalah motivasi belajar. Terkait dengan peran motivasi belajar, Puspawati (2010) dalam penelitiannya menemukan bahwa faktor motivasi belajar berpengaruh terhadap hasil belajar matematika siswa. Pembahasan lebih lanjut dikatakan bahwa motivasi belajar terkait dengan dorongan untuk terlibat aktif dalam suatu kegiatan belajar, baik yang berasal dari diri siswa sendiri maupun dari luar diri siswa. Dalam konteks penelitian ini, pembelajaran kooperatif tipe Co-op Co-op relatif baru digunakan dalam pembelajaran matematika khususnya pada kompetensi memahami sifatsifat BRL (bangun ruang sisi lengkung). Oleh karena itu motivasi belajar merupakan faktor yang penting dipertimbangkan dalam penelitian ini.

Berdasarkan uraian di atas, menunjukkan bahwa model pembelajaran dengan menggunakan tipe Co-op Co-op sangat diperlukan untuk meningkatkan hasil belajar matematika khususnya pada kompetensi memahami sifat-sifat tabung, kerucut dan bola serta menentukan ukurannya. Untuk itu dipandang perlu mengadakan penelitian lebih lanjut tentang" Penerapan Model Pembelajaran Kooperatif Tipe Co-op Co-op Untuk Meningkatkan Hasil Belajar Matematika dan Motivasi Belajar Siswa Kelas IX A SMP Negeri 2 Abang Tahun Pelajaran 2018/2019.

Pembelajaran kooperatif tipe Co-op Co-op benar-benar sama untuk investigasi kelompok. Ini menempatkan tim dalam kooperatif dengan yang lainnya untuk mempelajari suatu topik kelas. Bahkan Slavin (2008) menyatakan bahwa tiga tipe belajar kooperatif yang bisa diterapkan dalam spesialisasi tugas adalah investigasi kelompok (group investigation), Co-op, dan jigsaw. Co-op mengizinkan siswa untuk bekerja bersama dalam kelompok kecil, pertama untuk kemajuan pemahaman mereka mengenai diri mereka sendiri dan ruang, dan selanjutnya untuk kesediaan mereka dengan kesempatan untuk 
berbagi pemahaman baru itu dengan teman-teman sebaya mereka. Metodenya sederhana dan fleksibel. Suatu situasi seorang guru memegang filosofi di belakang Co-op Co-op, dia bisa memilih sejumlah cara untuk menerapkan pendekatan yang akan diberikan di dalam ruang-kelas. Slavin (2008) mengemukakan sembilan tahapan spesifik dalam peningkatan kemungkinan kesuksesan dari metode ini.

Dalam penelitian ini digunakan model pembelajaran kooperatif tipe Co-op Co-op di dalam pembelajaran matematika pada siswa kelas IX A SMP Negeri 2 Abang. Hal ini disebabkan karena pada dasarnya model pembelajaran kooperatif tipe Co-op Co-op sangat cocok untuk kompetensi memahami sifat-sifat BRL dan penelitian ini menggunakan spesialisasi tugas untuk setiap anggota kelompok. Untuk lebih jelasnya dirangkum dalam tabel berikut.

Tabel 1. Sintaks Pembelajaran Kooperatif Tipe Co-op Co-op

\begin{tabular}{|c|c|}
\hline Aktivitas Guru & Aktivitas Siswa \\
\hline $\begin{array}{l}\text { 1. Guru memberikan siswa untuk melakukan diskusi } \\
\text { kelas tentang topik yang akan dipelajari }\end{array}$ & $\begin{array}{l}\text { 1. Siswa secara sendiri atau kelompok } \\
\text { kecil mendiskusikan topik yang akan } \\
\text { dipelajari. }\end{array}$ \\
\hline $\begin{array}{l}\text { 2. Guru menyuruh siswa untuk membentuk tim. Siswa } \\
\text { diberikan kesempatan untuk membentuk tim sesuai } \\
\text { keinginan. }\end{array}$ & $\begin{array}{l}\text { 2. Siswa memilih tim belajar dan duduk } \\
\text { sesuai tim }\end{array}$ \\
\hline $\begin{array}{l}\text { 3. Guru mengundi Topik dan meminta siswa untuk } \\
\text { mengerjakan topik sesuai pilihan mereka. }\end{array}$ & $\begin{array}{l}\text { 3. Siswa secara berkelompok membahas } \\
\text { topik yang dipilih. }\end{array}$ \\
\hline $\begin{array}{l}\text { 4. Guru mengelilingi siswa sambil melihat mini topik } \\
\text { masing-masing kelompok. }\end{array}$ & $\begin{array}{l}\text { 4. siswa mengerjakan topik melalui diskusi } \\
\text { kelompok, jawaban siswa disiapkan. }\end{array}$ \\
\hline 5. Guru menyuruh presentasi topik untuk anggota tim & 5. Siswa presentasi untuk anggota timnya. \\
\hline $\begin{array}{l}\text { 6. Guru memberikan waktu kepada masing -masing tim } \\
\text { untuk presentasi, selama presentasi tim mengambil } \\
\text { kontrol ruangan kelas . }\end{array}$ & $\begin{array}{l}\text { 6. Siswa mempresentasikan topik yang } \\
\text { dibahas bersama anggota kelompoknya. }\end{array}$ \\
\hline $\begin{array}{l}\text { 7. Guru mengevaluasi presentasi mini topik dari } \\
\text { masing-masing tim }\end{array}$ & $\begin{array}{l}\text { 7. Siswa menampilkan tulisan atau } \\
\text { presentasi dari masing-masing siswa. }\end{array}$ \\
\hline
\end{tabular}

Hasil belajar matematika adalah hal-hal yang dimiliki siswa setelah ia menerima pengalaman belajarnya dalam pembelajaran matematika. Hasil belajar yang dimiliki adalah kemampuan aktual yang dapat diukur dan berwujud penguasaan ilmu pengetahuan, sikap, ketrampilan dan nilai-nilai yang dicapai siswa sebagai hasil proses belajar mengajar. Kingsley (dalam Sujana, 2004) membagi membagi tiga macam hasil belajar, yaitu (a) ketrampilan dan kebiasaan, (b) pengetahuan dan pengertian, (c) sikap dan cita-cita. Masing - masing jenis hasil belajar dapat diisi dengan bahan yang telah ditetapkan dalam kurikulum. Sedangkan Gagne (dalam Dahar, 1989) membagi lima kategori hasil belajar, yaitu keterampilan intelek (intellectual skill), strategi kognitif (cognitive strategies), informasi verbal (verbal information), keterampilan gerak (motor skill), dan sikap (attitudes).

Dalam pembelajaran matematika setidaknya ada empat hal yang perlu diperhatikan dalam menilai hasil belajar siswa. Pertama, penilaian pendidikan ditujukan untuk menilai hasil belajar siswa secara menyeluruh, mencakup aspek kognitif dan afektif. Informasi hasil belajar yang menyeluruh menuntut berbagai bentuk sajian, yakni berupa angka hasil, kategori dan deskriptif naratif sesuai dengan aspek yang dinilai. Informasi dalam bentuk angka cocok untuk menyajikan hasil dalam aspek kognitif. Sajian dalam bentuk kategorisasi disertai dengan deskriptif naratif cocok untuk melaporkan aspek afektif. Kedua, hasil penilaian pendidikan dapat digunakan untuk menentukan pencapaian kompotensi dan melakukan pembinaan dan pembimbingan pribadi siswa. Ketiga, penilaian oleh pendidik terutama ditujukan untuk pembinaan hasil dan pengembangan potensi siswa. Keempat untuk memperoleh data yang lebih dapat dipercaya sebagai dasar pengambilan keputusan perlu digunakan banyak penilaian yang dilakukan secara berulang dan berkesinambungan. (Depdiknas, 2004).

Morgan et al. (dalam Marwansyah dan Mukaram, 2002) menjelaskan bahwa: "motivasi merupakan kekuatan yang mengendalikan dan menggerakkan seseorang untuk melakukan tindakan atau perilaku yang diarahkan pada tujuan tertentu“. Barton dan Martin (dalam Marwansyah dan Mukaram, 2002) menjelaskan bahwa: "motivasi merupakan kekuatan yang menggerakkan perilaku yang memberi arah pada perilaku dan mendasari kecenderungan untuk tetap menunjukkan perilaku tersebut."

Djamarah (2002) menyataka bahwa motivasi sebagai perubahan energi dalam diri seseorang yang ditandai dengan munculnya feelling dan didahului dengan tanggapan terhadap adanya tujuan. Perubahan energi dalam diri seseorang itu berbentuk suatu aktivitas nyata berupa kegiatan fisik. Karena 
seseorang mempunyai tujuan tertentu dari aktivitasnya, maka seseorang mempunyai motivasi yang kuat untuk mencapainya dengan segala upaya yang dapat ia lakukan untuk mencapainya.

Dalam proses belajar, motivasi sangat diperlukan, sebab seseorang yang tidak mempunyai motivasi dalam belajar, tidak akan mungkin melakukan aktivitas belajar. Hal ini merupakan suatu pertanda, bahwa sesuatu yang akan dikerjakan itu tidak menyentuh kebutuhannya. Segala sesuatu yang menarik minat orang lain belum tentu menarik minat orang tertentu selama sesuatu itu tidak bergantung dengan kebutuhannya. Oleh karena itu, apa yang seseorang lihat sudah tentu akan membangkitkan minatnya sejauh apa yang ia lihat itu mempunyai hubungan dengan kepentingannya sendiri.

Morgan (dalam Slameto, 1989) menjelaskan motivasi bertalian dengan tiga hal. Ketiga hal tersebut adalah "keadaan yang mendorong tingkah laku (motivating states), tingkah laku yang didorong oleh keadaan tersebut (motivated behavior), dan tujuan daripada tingkah laku tersebut (gool or ends of such behavior). Senada dengan Morgan, lebih lanjut Hamalik (2002) menjelaskan bahwa "motivasi adalah suatu perubahan energi di dalam peribadi seseorang yang ditandai dengan timbulnya afektif dan reaksi untuk mencapai tujuan“. Pendapat di atas, mengandung tiga unsur yang saling berkaitan, yaitu: 1) motivasi dimulai dari adanya perubahan energi dalam pribadi, 2) motivasi ditandai dengan timbulnya perasaan (affective arousal), 3) motivasi ditandai oleh reaksi-reaksi untuk mencapai tujuan. Unsur-unsur yang dimaksud adalah:

1) motivasi dimulai dengan adanya perubahan energi dalam pribadi. Perubahan-perubahan dalam motivasi timbul dari perubahan-perubahan tertentu di dalam sistem neurofisiologis dalam organisme manusia. Contoh adanya perubahan dalam sistem pencernaan akan menimbulkan motif lapar. Akan tetapi, ada juga perubahan energi yang tidak diketahui,

2) motivasi ditandai timbulnya perasaan (affective arousal) mula-mula merupakan ketegangan psikologis, lalu merupakan suasana emosi. Suasana emosi ini menimbulkan kelakuan yang bermotif. Perubahan ini mungkin disadari, mungkin juga tidak. Kita dapat mengamatinya pada perbuatan. Contoh siswa terlibat dalam diskusi. Karena dia merasa tertarik pada masalah yang dibicarakan, dia akan berbicara dengan kata-kata dan suara yang lancar dan cepat, dan

3) motivasi ditandai oleh reaksi-reaksi untuk mencapai tujuan. Pribadi yang bermotivasi mengadakan respons-respons yang tertuju ke arah suatu tujuan. Respons-respons itu berfungsi mengurangi ketegangan yang disebabkan oleh perubahan energi dalam dirinya. Setiap respons merupakan suatu langkah ke arah pencapaian tujuan. Contoh siswa ingin mendapat hadiah, maka ia akan belajar, mengikuti ceramah, bertanya, membaca buku, mengikuti tes, dan sebagainya.

\section{Metode Penelitian}

Jenis penelitian yang dilakukan adalah penelitian tindakan kelas (PTK). Menurut Agung (2018:3) bahwa PTK merupakan suatu bentuk penelitian yang bersifat reflektif dengan melakukan tindakan-tindakan tertentu agar dapat memperbaiki dan atau meningkatkan praktek-praktek pembelajaran di kelas secara lebih profesional. Sejalan dengan pengertian PTK tersebut, Arikunto (2002) menyatakan bahwa secara umum PTK bertujuan meningkatkan dan memperbaiki kualitas proses pembelajaran di kelas tempat berlangsungnya penelitian. Tindakan yang dilakukan dalam penelitian ini adalah penerapan model pembelajaran Berbasis masalah. Penelitian ini dilaksanakan pada kelas IX A yang mempunyai masalah pembelajaran. Subjek penelitian ini adalah siswa kelas IX A SMP Negeri 2 Abang semester ganjil tahun ajaran 2018/2019, dengan jumlah siswa 30 orang. Objek dari penelitian tindakan kelas ini terdiri dari dua jenis yaitu objek tindakan berupa implementasi model pembelajaran kooperatif tipe Co-Op Co-Op dan objek amatan berupa hasil belajar matematika dan motivasi belajar matematika siswa.

Penelitian ini dibagi dalam dua siklus dengan masing-masing siklus terdiri dari empat tahapan yaitu: (1) perencanaan, (2) tindakan, (3) observasi/evaluasi, dan (4) refleksi. Desain penelitian ini dapat digambarkan seperti Gambar 3.1. 


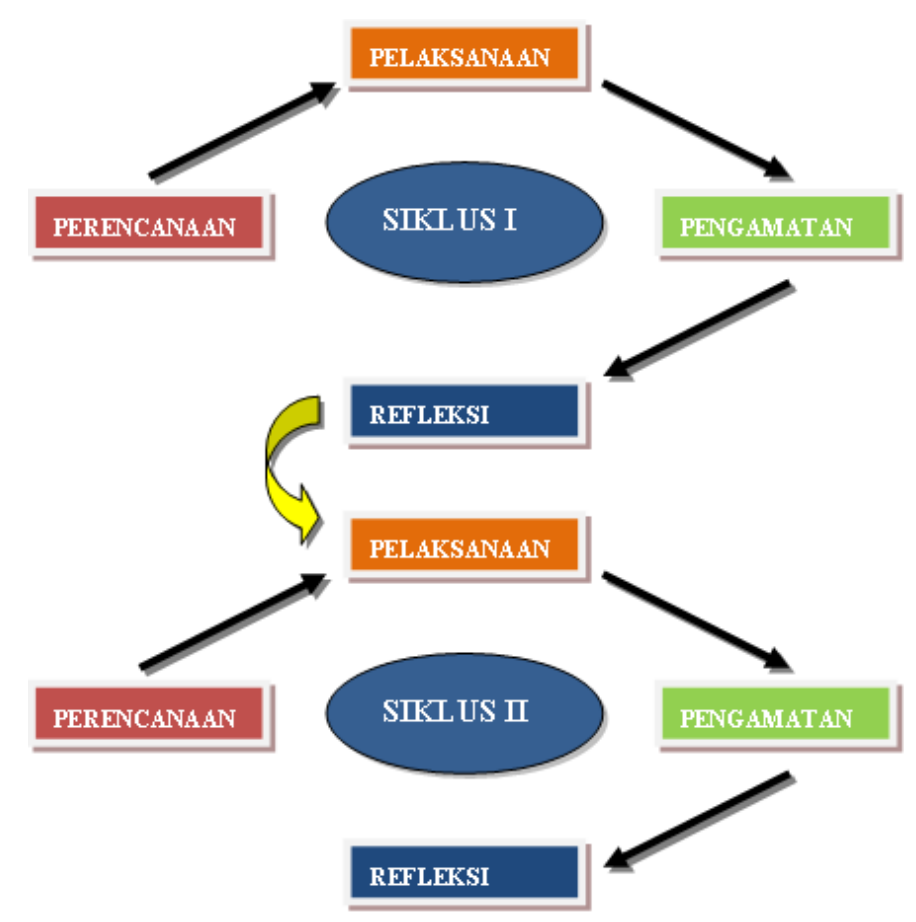

Gambar 1. Tahapan dalam Siklus Pembelajaran

Data-data yang dikumpulkan dalam penelitian ini adalah hasil belajar matematika dan motivasi belajar. Data hasil belajar siswa dikumpulkan dengan menggunakan tes hasil belajar yang berbentuk objektif. Masing-masing siklus terdiri dari 15 butir soal dengan skor maksimal untuk masing-masing butir adalah 1. Skor maksimal yang dapat diperoleh oleh siswa adalah 15 dan skor minimal adalah 0. Skor tersebut dikonversikan ke skala 100 untuk menentukan tingkat daya serap siswa terhadap materi yang diajarkan.

Motivasi belajar dikumpulkan dengan menggunakan kuesioner motivasi belajar yang terdiri dari 2 dimensi yang dikembangkan menjadi 8 indikator motivasi belajar siswa. Siswa dikatakan tuntas jika $\bar{X} \geq 76$ dan satu kelas dikatakan tuntas jika $\mathrm{KK} \geq 85 \%$. Hal ini sesuai dengan yang ditetapkan oleh SMP Negeri 2 Abang pada semester ini. Penelitian ini dikatakan berhasil bila rata-rata $(\bar{X})$ pencapaian minimal 76 atau berada pada kategori tinggi dan ketuntasan klasikal (KK) minimal 85\%. Peningkatan pada hasil belajar dianalisis dengan rata-rata skor yang diperoleh oleh siswa dalam satu kelas ( $\bar{X}$ ) pada siklus I dibandingkan dengan rata-rata yang diperoleh siswa pada siklus II. Hasil belajar siswa dikatakan meningkat jika rata-rata nilai siklus II lebih besar dari rata-rata siklus I dan memenuhi kriteria ketuntasan minimal yang ditetapkan.

Motivasi belajar dikumpulkan dengan menggunakan kuesioner yang terdiri dari 10 butir pernyataan dengan skor untuk masing-masing butir menggunakan skala Likert 1 sampai dengan 5 . Berdasarkan skala tersebut maka skor maksimum ideal yang mungkin dicapai siswa adalah 50 dan skor minimal adalah 10. Skor tersebut kemudian dikonversikan ke dalam skala seratus (100) untuk menentukan pencapaian motivasi belajar. Penelitian ini dikatakan berhasil jika terjadi peningkatan ratarata motivasi belajar siswa dari siklus I ke siklus berikutnya dengan memiliki kualifikasi minimal tinggi.

\section{Hasil dan Pembahasan}

Hasil penelitian menunjukkan bahwa penerapan model pembelajaran kooperatif Co-Op Co-Op dapat meningkatkan hasil belajar dan motivasi belajar siswa dalam pembelajaran matematika Siswa Kelas IX A SMP Negeri 2 Abang Tahun Pelajaran 2018/2019. Pada observasi awal rata-rata hasil belajar matematika siswa 69,20 dengan ketuntasan belajar 50\% meningkat ke siklus I menjadi 75,80 dengan ketuntasan belajar 66,70\% dan meningkat pada siklus II menjadi 87,10 dengan ketuntasan belajar 93,30\%. Hasil ini menunjukkan terjadi peningkatan hasil belajar dari observasi awal ke siklus I, dan dari siklus I ke siklus II. Untuk aspek motivasi belajar pada siklus I memiliki rata-rata sebesar 75,10 dengan kategori sedang. Meningkat pada siklus II dengan rata-rata 87,10 dengan ketegori tinggi. Berdasarkan 
hasil analisis tampak bahwa terjadi peningkatan motivasi belajar siswa sebesar 16,00\% dari kualifikasi sedang ke kualifikasi tinggi.

Penerapan model pembelajaran kooperatif tipe Co-op Co-op merupakan hal yang mendukung terciptanya proses pembelajaran yang lebih menumbuhkan pemahaman siswa akan materi yang diajarkan. Model pembelajaran kooperatip tipe Co-op Co-op ditujukan untuk menumbuhkan dan membantu pemahaman siswa dalam memahami materi. Untuk mewujudkan hal tersebut diperlukan upaya untuk merancang dan melakukan pembelajaran dengan lebih mengutamakan diskusi antar teman sebaya. Dengan model pembelajaran kooperatip tipe Co-op Co-op membuat rumus-rumus matematika yang menakutkan yang sebenarnya adalah hal yang menceritakan sesuatu dengan bahasa yang lain menjadikan sesuatu yang mudah dipahami karena dipelajari dengan suasana santai . Jadi siswa akan dapat memahami konsep-konsep yang mereka pelajari melalui pengalaman langsung dan nyata. Seiring dengan hal tersebut, penerapan model pembelajaran kooperatif tipe Co-op Co-op merupakan konsep belajar yang menunjang dasar pemikiran belajar alamiah, dan pola belajar menyenangkan. Pengaruh pembelajaran kooperatif dalam pembelajaran merupakan model yang membantu guru mengaitkan materi yang diajarkan dengan situasi dunia bermain dan mendorong siswa membuat hubunganhubungan antara pengetahuan dasar yang dimiliki dan penerapannya, sehingga hasil pembelajaran lebih bermakna bagi siswa karena siswa ikut melakukan, bekerja sama, dan mengalami.

Penerapan model pembelajaran koperatif tipe Co-op Co-op pada siswa yang memiliki motivasi belajar tinggi akan mampu meningkatkan kreativitas dan mengembangkan kemampuannya secara optimal, karena dalam proses pembelajaran dengan model pembelajaran kooperatif tipe Co-op Co-op mereka dilibatkan secara aktif mengikuti tahapan-tahapan pembelajaran dengan kerjasama yang mampu menggambarkan secara real materi yang sedang dipelajarinya. Dengan demikian, pembelajaran akan terasa lebih bermakna karena melibatkan siswa secara keseluruhan dalam proses pembelajaran. Sementara untuk siswa yang memiliki minat belajar tinggi jika diberikan model pembelajaran konvensional yang berpusat pada guru (teacher center), akan merasa terbelenggu dan memungkinkan siswa merasa jenuh dalam menerima materi pelajaran sebatas yang diterangkan oleh guru. Mereka tidak memiliki kesempatan dalam mengekplorasikan diri secara optimal, sehingga hasil belajar yang dicapai juga tidak akan maksimal.

\section{Simpulan}

Berdasarkan hasil analisis data dapat disimpulkan bahwa penerapan model pembelajaran kooperatif tipe co-op co-op dapat meningkatkan hasil belajar matematika siswa kelas IX A SMP Negeri 2 Abang Tahun Pelajaran 2018/2019. Pada observasi awal rata-rata hasil belajar matematika siswa 69,20 dengan ketuntasan belajar 50\% meningkat pada siklus I menjadi 75,80 dengan ketuntasan belajar $66,70 \%$. Pada siklus II meningkat menjadi 87,10 dengan ketuntasan belajar 93,30\%. Penerapan model pembelajaran kooperatif tipe co-op co-op dapat meningkatkan motivasi belajar matematika siswa kelas IX A SMP Negeri 2 Abang Tahun Pelajaran 2018/2019. Untuk variabel motivasi belajar matematika pada siklus I diperoleh rata-rata skor sebesar 75,10 dengan kategori sedang dan meningkat pada siklus II dengan rata-rata 87,10 dengan ketegori tinggi. Berdasarkan hasil analisis tampak bahwa terjadi peningkatan motivasi belajar matematika siswa sebesar 16,00\% dari kualifikasi sedang ke kualifikasi tinggi. Berdasarkan simpulan hasil penelitian tersebut, dapat diajukan saran-saran sebagai berikut: a) kepada lembaga pendidikan yang terkait disarankan dapat mensosialisasikan model-model pembelajaran yang mengarah kepada pola pembelajaran kreatif salah satunya model pembelajaran kooperatif tipe Coop Co-op kepada para guru bidang studi maupun guru kelas sebagai alternatif melalui kegiatan-kegiatan seminar, pelatihan-pelatihan, maupun dalam pertemuan kelompok kerja guru; b) kepada teman-teman guru khususnya guru sekolah menengah bidang studi pada umumnya disarankan untuk mencoba menggunakan model pembelajaran kooperatif tipe co-op Co-op dalam proses pembelajaran, karena model ini terbukti menjadikan hasil belajar siswa khususnya dalam bidang matematika lebih tinggi dibandingkan menggunakan model pembelajaran konvensional.

\section{Daftar Rujukan}

Agung. A. A. G. 2018. Konsep dan Teknik Analisis Data Penelitian Tindakan Kelas (PTK). Singaraja: Fakultas Ilmu Pendidikan Universitas Pendidikan Ganesha.

Arikunto, S. 2002. Prosedur Penelitian. Jakarta: Rineka Cipta. 
Depdiknas, 2004. Petunjuk Teknis Mata Pelajaran matematika. Jakarta: Direktorat Pendidikan dasar dan Menengah.

Djamarah, S. B. 2002. Prestasi Belajar dan Kompetensi Guru. Surabaya: Usaha Nasional.

Hamalik, 0. 2002. Psikologi Belajar dan Mengajar. Bandung: Sinar Baru.

Lasmawan, I W. 2011. Penelitian Tindakan Kelas. (PTK). Singaraja: IKIP Negeri Singaraja.

Marhaeni, AAIN. 2005. Pengaruh Asesmen Portofolio dan Motivasi Berprestasi dalam Belajar Bahasa Inggris Terhadap Kemampuan Menulis Bahasa Inggris (Studi Eksperimen pada Mahasiswa Jurusan Pendidikan Bahasa Inggris IKIP Negeri Singaraja, 2004). Desertasi: IKIP Negeri Jakarta.

Murwansyah dan Mukaram. 2002. Manajemen Sumber Daya Manusia. Bandung: Pusat Penerbit Administrasi Niaga Politeknik Negeri Bandung, Indonesia.

Puger, K. 2004. Belajar dan hasil belajar. Bandung: Sinar Baru.

Puspawati. 2010. Pengaruh Metode Pembelajaran Kooperatif Tipe STAD Terhadap Prestasi Belajar Matematika pada Siswa Kelas III SMP Negeri 3 Mendoyo (Eksperimen pada Pokok Bahasan lingkaran). Tesis. Program Pascasarjana IKIP Negeri Singaraja.

Slameto. 1989. Belajar dan Faktor-faktor yang Mempengaruhi. Jakarta: Bina Aksara.

Slavin, Robert E. 2008. Cooperative Learning Teori, Riset dan Praktek. Bandung: Nusa Media.

Sujana, N. 2004. Penilaian Hasil Proses Belajar Mengajar. Bandung: PT Remaja Rosda Karya. 